\title{
Dinâmica do mercado imobiliário nos centros históricos em tempos de globalização: os casos do Recife, Belém e São Luís (Brasil)*
}

\author{
Dynamics of the real estate market in historic centers in times \\ of globalization: the cases of Recife, Belém and São Luís (Brazil)
}

\author{
Norma Lacerda ${ }^{[]]}$ \\ Helena Lúcia Zagury Tourinho[II] \\ Marco Aurélio Arbage Lôbo [III] \\ Marluce Wall de Carvalho Venâncio ${ }^{[\mathrm{V}]}$
}

\section{Resumo}

As baixas taxas de crescimento da economia brasileira e a sua inserção na economia globalizada, verificadas a partir da década de 1990, tiveram repercussões sobre os centros históricos. A descentralização político-administrativa e a competição entre as cidades pelos investimentos privados impulsionaram os governos locais a investir nesses centros para atrair atividades. Isso tem tido implicações nas dinâmicas dos seus respectivos mercados imobiliários. 0 presente texto analisa, comparativamente, como essas dinâmicas ocorreram nos Centros Históricos do Recife, de Belém e de São Luís, bem como em seus espaços internos, mostrando suas regularidades e especificidades. Revela que ora se reproduzem espacialidades preexistentes, ora se recriam outras mediante processos de requalificação capazes de inseri-los, de diferentes maneiras, no processo de globalização da economia.

Palavras-chave: centro histórico; mercado imobiliário; globalização, dinâmica espacial, requalificação urbana.

\begin{abstract}
The slow growth of Brazilian economy since the 1990s and its insertion into the global economy have brought consequences for historic centers. Political-administrative decentralization and competition among cities for private investment have prompted local governments to invest in these centers to attract activities, which has affected their real estate market dynamics. This article compares how these market dynamics have occurred in the Historic Centers of Recife, Belém and São Luís (Northeastern Brazil) and the effects on their spatial organization, showing their regularities and specificities. As a result of these dynamics, pre-existing spaces (degraded areas) are sometimes reproduced or, otherwise, recreated by way of requalification. This reveals the different ways in which these centers are inserted in the global economy.
\end{abstract}

Keywords: historic center; real estate market; globalization; spatial dynamics; urban requalification. 


\section{Introdução}

Várias têm sido as análises sobre os recentes processos de intervenção urbanística em centros históricos brasileiros. Em geral, esses estudos têm-se concentrado nas mudanças dos perfis socioeconômicos das atividades lá existentes, ou mesmo na dinâmica demográfica, com ênfase nos processos de gentrificação el ou de reconversão urbana, especialmente para fins de moradia. Com isso, apesar da centralidade atual do tema - centro histórico - , até o início da presente década, permaneceu uma lacuna, em termos de estudos a seu respeito, em condições de subsidiar o entendimento das implicações desses processos sobre o funcionamento do mercado imobiliário nesses espaços. Isso motivou o desenvolvimento da pesquisa, que envolve os centros históricos do Recife, Belém e São Luís, iniciada em 2012.

Tais processos de intervenção urbanística, em especial os verificados a partir dos anos 1990, acham-se intrinsecamente associados às baixas taxas de crescimento da economia brasileira e ao decorrente movimento da sua inserção no mundo globalizado, movimento este que insere, diferentemente, os centros históricos - total ou parcialmente - nos seus circuitos econômicos.

Segundo Santos (2008), as economias não desenvolvidas estão segmentadas em duas partes que, a despeito de suas profundas diferenças, funcionam de forma articulada no processo de acumulação de capital. 0 circuito superior é constituído por atividades caracterizadas por apresentar: alta tecnologia; organização formal; relevantes inversões de capitais; qualidade elevada de produtos e serviços; baixa geração de emprego com elevados rendimentos e salários. Já o circuito inferior é formado, predominantemente, por atividades de: baixa tecnologia; organização predominantemente informal; preços baixos e qualidade inferior de produtos e serviços; alta capacidade de absorção da força de trabalho com rendimentos e salários reduzidos.

Silveira (2007), por sua vez, ressalta a forte interface dos dois circuitos e denomina circuito superior marginal a miríade de atividades que se distribuem em áreas de diversidade e especialização funcional, muitas delas situadas em centros comerciais tradicionais, em imóveis antigos ou pouco conservados. Tais atividades, normalmente de pequeno porte, combinam tecnologias e formas de organização tradicionais com tecnologias avançadas disponibilizadas pela popularização dos recursos da informática.

As dinâmicas socioespaciais endógenas, associadas à maneira como os espaços centrais históricos se incorporam à economia globalizada, são fundamentais para a compreensão das transformações que se vêm realizando nos referidos centros históricos; transformações que, em última instância, são operadas pelos seus respectivos mercados imobiliários.

Importa anotar que diversas análises já foram realizadas sobre cada um dos centros estudados no âmbito da referida pesquisa. Restava desenvolver um estudo que confrontasse os resultados alcançados em cada um deles. Daí o objetivo deste artigo: comparar as recentes dinâmicas socioespaciais dos mercados imobiliários de aluguel e de compra e venda nos centros históricos das cidades do Recife, Belém e São Luís. 
Para isso, primeiramente, enfocam-se as intervenções urbanísticas realizadas a partir do início do século XX nos três centros. Posteriormente, utilizando-se dados dos Censos Demográficos do IBGE de 1991 e 2010, desagregados por bairros, expõe-se a evolução do submercado de locação residencial, mostrando as diferenças observadas no interior de cada um dos centros estudados e entre eles. Por fim, com base em dados do Imposto de Transmissão de Imóveis (ITBI), as atenções voltam-se para o mercado de compra e venda, enfocando apenas os Centros Históricos de Recife e de Belém, pois não há dados disponíveis para o Centro Histórico de São Luís.

\section{Intervenções urbanísticas}

Convém, logo de início, anotar que se considerou a delimitação do centro histórico de cada cidade a partir de critérios aceitos localmente. Assim sendo, o Centro Histórico do Recife (CHR) corresponde ao conjunto de Zonas Especiais de Patrimônio Histórico-Cultural que compreende parte do bairro da Boa Vista e pequenos trechos dos bairros da Soledade, Santo Amaro e Coelhos - doravante chamados de bairro da Boa Vista; assim como a totalidade dos bairros do Recife e de Santo Antônio e uma porção do bairro de São José (Figura 1).

\section{Figura 1 - Centro Histórico do Recife (CHR)}

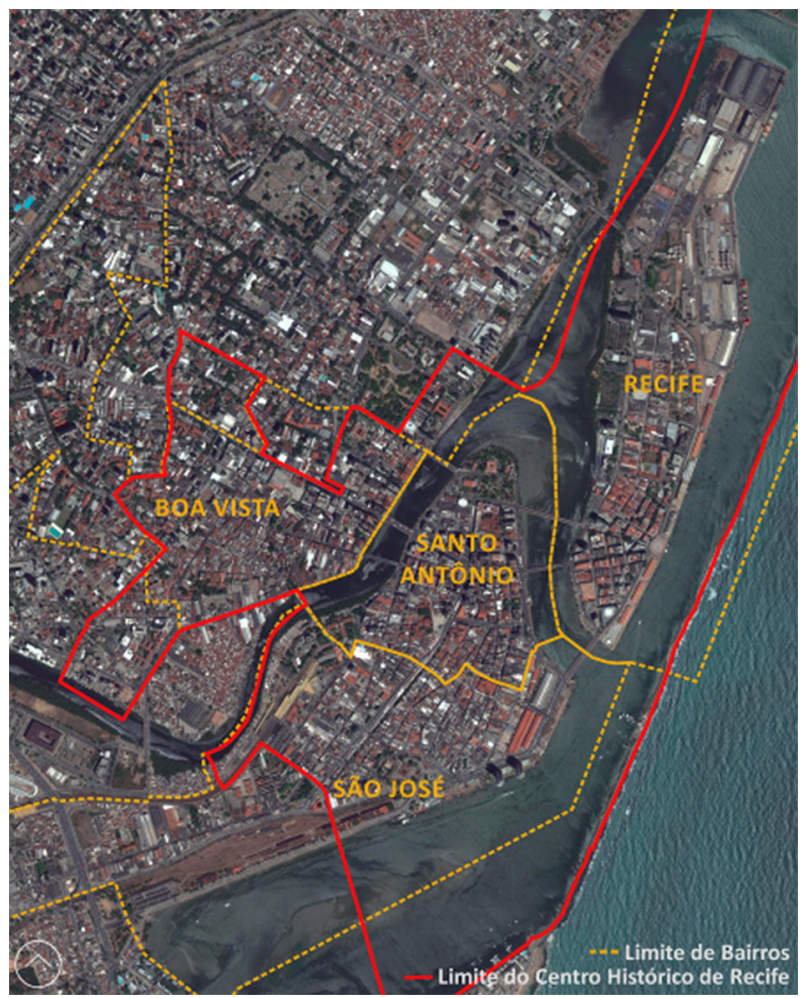

Fonte: GEMFI, 2018. Adaptado a partir do Google Satélite (delimitação aproximada do CHR). 
Figura 2 - Centro Histórico de Belém (CHB)

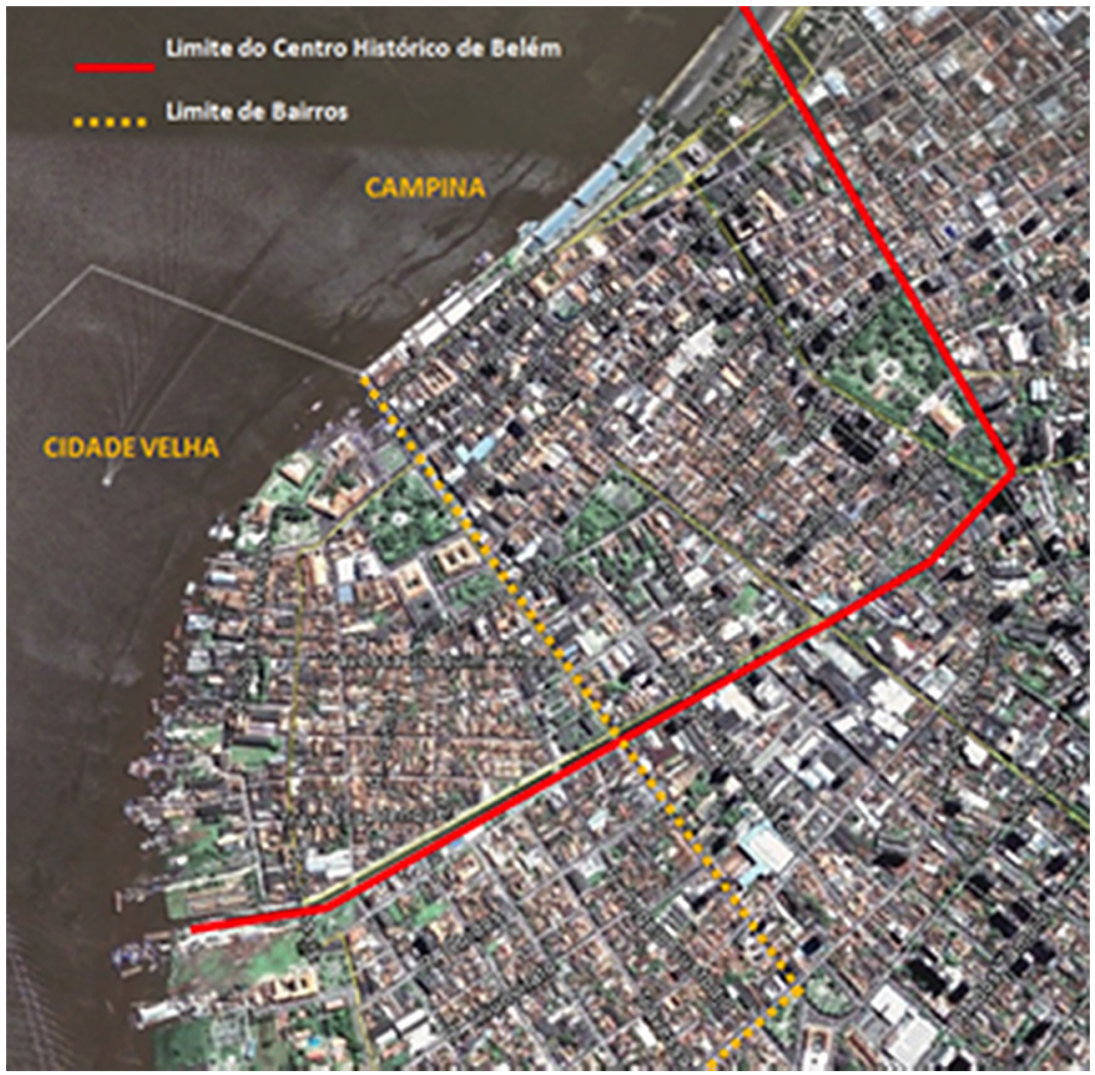

Fonte: Google Maps (delimitação aproximada do CHB).

Quanto ao Centro Histórico de Belém (CHB), adotou-se o perímetro estabelecido pela lei municipal n. 7.790, de maio de 1994, excluindo a área do porto, localizada nos bairros do Reduto e do Umarizal. Assim sendo, foram considerados como integrantes do CHB o bairro da Campina e parte do bairro da Cidade VeIha, conforme demarcado na Figura 2.
0 Centro Histórico de São Luís (CHSL), para fins do presente estudo, compreende as áreas de tombamento federal e da Unesco e parte da área de tombamento estadual (Figura 3). Nesse caso, não foi feita a divisão em bairros, em razão de não existir uma delimitação oficial, ou seja, uma Lei dos Bairros na cidade. 
Figura 3 - Centro Histórico de São Luís

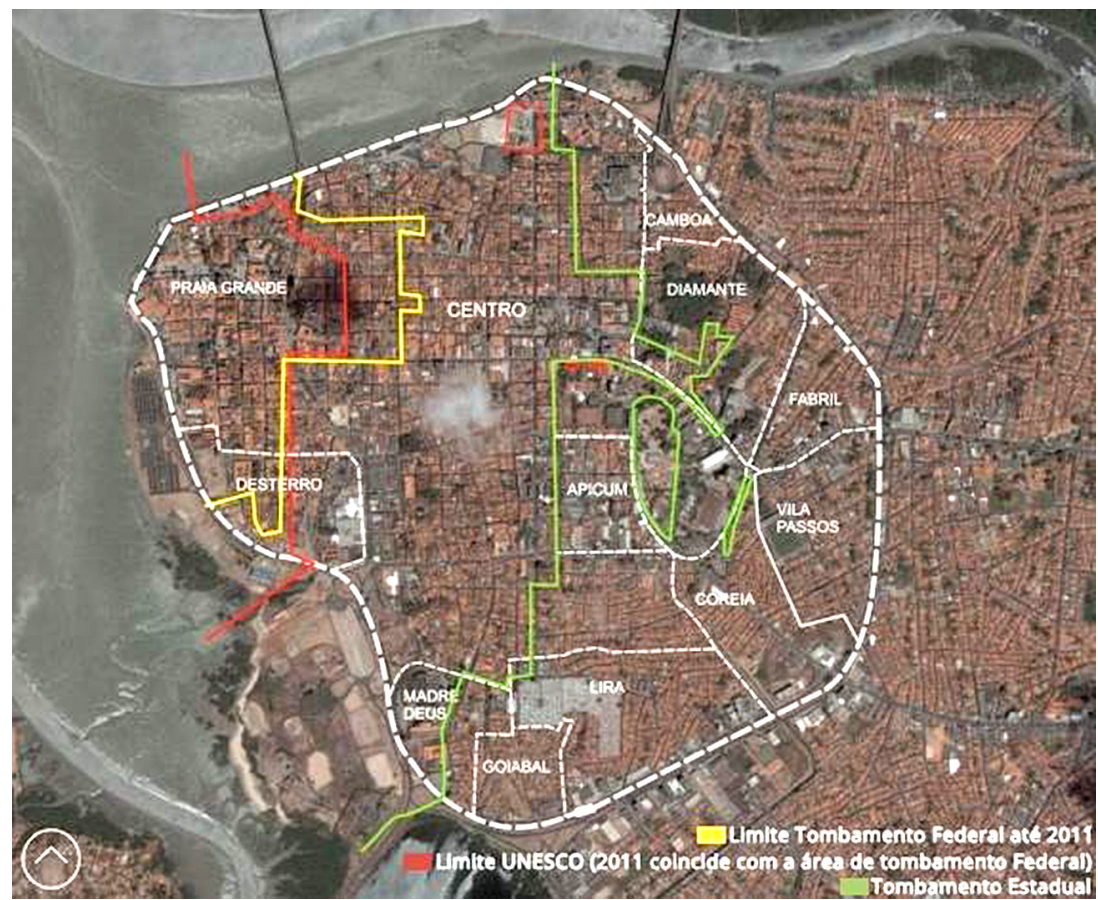

Fonte: Venancio (2011), adaptado a partir do Google Maps.

Para que se possa apreender a dinâmica socioespacial do mercado imobiliário desses centros, é imprescindível, como anotado introdutoriamente, identificar as transformações, gerais e específicas, que eles têm vivenciado, sobretudo as realizadas a partir do início do século XX.

\section{No Centro Histórico do Recife ${ }^{1}$}

No final do século XIX, o CHR já era bastante diferenciado internamente. Embora concentrasse o comércio açucareiro e as grandes firmas importadoras, o bairro do Recife era um espaço degradado. Não sem razão, recebeu melhorias nas suas infraestruturas portuária e sanitária, além de intervenções por meio do Plano de Reforma do Bairro do Recife. Com a reforma, essa porção territorial, que abrigava 13.204 habitantes, em 1910, passou a acolher apenas 5.146, em 1913 (Lubambo, 1991). Assumia ela novas funções, deixando para o bairro de Santo Antônio a função administrativa (Palácio do Governo, Quartel, etc.), cultural (Teatro Santa Isabel) e religiosa, além da habitacional.

0 bairro de Santo Antônio só começou a ser objeto de intervenção a partir de 1938, 
quando a avenida Guararapes foi alargada e se estabeleceu a volumetria do seu entorno. A segunda grande intervenção, que ocorreu a partir de 1950, contemplou, além desse bairro, o de São José e visou à abertura da avenida Dantas Barreto. A terceira decorreu da legislação urbanística de 1953 que, a partir de um zoneamento da área central, estabeleceu uma nova volumetria para o bairro, o que resultou em intensa ocupação e verticalização. 0 ponto comum a esses três tipos de intervenção foi que trouxeram, como consequência, a valorização imobiliária do CHR.

Paralelamente, o Serviço de Proteção ao Patrimônio Histórico e Artístico Nacional (Sphan) tombou, em 1938, várias igrejas dos bairros de Santo Antônio e São José. Todavia, só a partir de 1946 - quando da criação do Distrito do Recife -, foi iniciada uma atuação de proteção, em articulação com o governo municipal. Constitui um marco dessa articulação o Plano de gabaritos dos bairros de Santo Antônio e São José (1965), que estabeleceu zonas de maior ou menor número de pavimentos em função da proteção da visibilidade dos bens tombados. Limitava-se, por essa via, a verticalidade proposta pela normativa de 1953, e reduzia-se a possibilidade de aproveitamento construtivo dos terrenos nesses bairros. Isso teve impactos negativos em termos de valorização imobiliária, agravados com 0 Plano de preservação dos sítios históricos do Recife (1979), por meio do qual foram institucionalizados 31 sítios, dentre os quais os da área central. Tal normativa vigorou até 1996, quando a Lei de uso e ocupação do solo do Recife, ainda em vigor, incorporou as determinações do Plano de preservação.
Ao analisar a evolução da legislação urbanística no CHR, Reynaldo (1998) ressalta que, desde a sua primeira versão, em 1916, as leis foram baseadas no pensamento higienista e assinalaram que casas conjugadas e sobrados não atendiam às condições de salubridade, pelo que eram imprestáveis para a moradia. Não sem razão, o CHR foi sendo abandonado pelas classes de maior poder aquisitivo, abrindo as portas para os segmentos de mais baixa renda.

A grande repercussão em termos de preços do metro quadrado construído ocorreu quando o CHR foi retirado da agenda da promoção de compra e venda de unidades residenciais novas direcionadas à classe média, estimulada, a partir do início da década de 1970, pelo Banco Nacional da Habitação (BNH). Bairros residenciais tradicionais do Recife $-\mathrm{a}$ exemplo do Espinheiro e das Graças - foram paulatinamente transformados, dando lugar a uma ocupação vertical, com forte densidade construtiva e populacional, o que atraiu, para eles, o terciário "nobre" que foi abandonando o CHR e criando novas centralidades. Daí para a frente, parte importante dos antigos moradores desse centro passou a acompanhar essa dinâmica espacial.

Na década de 1990, o Brasil ingressou, de forma mais intensa, no processo de globalização da sua economia, abrindo-se e estruturando-se segundo o critério de vantagens comparativas. Inaugurou-se, então, a fase de acumulação flexível. Como se sabe, a globalização manifesta-se em vários domínios, sendo uma de suas formas a concorrência urbana. Nesse contexto, o governo do estado de Pernambuco elegeu o bairro do Recife como um dos territórios de atração de investidores. 
Para tanto, desenvolveu, em 1992, o Plano de revitalização do bairro do Recife, com o declarado objetivo de torná-lo um centro regional de serviços modernos, de comércio, de lazer e de cultura, para a população da cidade, e um centro de atração turística nacional e internacional. Nesse âmbito, foram recuperadas infraestruturas e imóveis, sendo estes destinados, principalmente, a bares e restaurantes. A partir do final da década de 1990, algumas dessas atividades fecharam suas portas, na medida em que não existia demanda gerada por outras atividades no próprio bairro.

Em 2000, o Governo do Estado de Pernambuco lançou o Projeto Porto Digital Empreendimentos e Ambiente Tecnológico, a partir do envolvimento das esferas pública, privada e acadêmica, com foco em tecnologia da informação e comunicação (TIC), a ser localizado no bairro do Recife. Para recepcionar as empresas, foram feitos investimentos na implantação de $8 \mathrm{~km}$ de fibras óticas e $26 \mathrm{~km}$ de dutos de ventilação e em saneamento. Em 2003, 46 edificações haviam sido recuperadas. Em 2015, 255 empresas haviam "embarcado" no Porto Digital e respondiam a aproximadamente 7.000 empregos (Lacerda e Fernandes, 2015).

Em 2006, incentivos fiscais (abatimento de $60 \%$ do valor do Imposto Sobre Serviços ISS) foram concedidos pela prefeitura do Recife às empresas de TIC ali instaladas. Em 2013, foi ampliada a abrangência territorial da isenção fiscal, o que significou incluir um quadrilátero no bairro de Santo Amaro, além dos bairros de Santo Antônio, São José e Boa Vista. Dois anos depois, houve uma nova expansão, que estendeu os incentivos fiscais para o bairro de Santo Antônio e partes dos bairros de São José e da Boa Vista, expansão justificada pela "falta de espaço" no bairro do Recife, o que, como se verá mais adiante, tem tido repercussões nos preços imobiliários que passaram a deter fortes componentes de monopólio locacional.

Acrescentem-se a essas intervenções as do Projeto Porto Novo, realizadas no Cais do Porto, em implantação desde 2012, responsáveis pela recuperação de antigos armazéns, com a intenção de integrar hotéis, lojas, escritórios, cinemas, centro de convenções e terminal marítimo de passageiros. 0 Projeto tem sido viabilizado por meio de recursos públicos e oriundos de parcerias público-privadas.

0 bairro Santo Antônio, a partir da segunda metade do ano 2000, foi redescoberto pelo setor privado, com ênfase no segmento de atividades universitárias, como resultado das políticas federais de incentivo ao ensino superior da década passada e início da presente década.

Quanto ao bairro de São José, até o presente, continua afastado da agenda dos investimentos públicos. Todavia, permanece sua tradicional função de comércio popular de âmbito local e regional. Tal comércio foi fortalecido com o aumento do poder aquisitivo das classes populares, possibilitado pelas políticas sociais do mencionado período e pela chegada dos comerciantes asiáticos. Em suas linhas centrais, o que se passou a assistir, notadamente nesse bairro, foi a comercialização de produtos globais populares, tanto legais quanto ilegais. Isso contribuiu para gerar e expandir múltiplos circuitos de distribuição e de comercialização. Tais circuitos resultaram em uma complexa imbricação de processos globais e locais, o que permite reconhecer 0 funcionamento de um circuito superior marginal, nos termos colocados introdutoriamente. 
Situação também vivenciada, como se verá adiante, no CHB.

No que se refere à Boa Vista, também não se observaram investimentos públicos. Nesse bairro persistem comércios especializados e o uso habitacional.

Depreende-se, da análise até aqui desenvolvida, que o CHR não é homogêneo. Circuitos econômicos globais nele incidiram para que se iniciasse uma metamorfose espacial que resultou na combinação de áreas renovadas e áreas degradadas. Assim, as suas diversas partes identificadas pelos vários níveis de qualidade das edificações e do espaço público, assim como pelas respectivas funcionalidades (áreas de TIC, lazer, educação, comércio especializado e residência, dentre outras) - assinalam uma nova divisão econômica e social do espaço (Dese). ${ }^{2}$ Mais ainda: testemunham a imbricação das políticas públicas nacionais e locais e das transformações espaciais.

\section{No Centro Histórico de Belém}

A área que hoje constitui o Centro Histórico de Belém (CHB) era o principal centro mercantil, político e religioso da cidade e da própria Região Amazônica no início do século XX. Em função do desenvolvimento proporcionado pela exploração da borracha, expressivas obras e inovações urbanas foram introduzidas nessa área da cidade desde o final do século XIX, tais como: a pavimentação de vias com paralelepípedos procedentes de Portugal; o paisagismo de várias praças públicas; a construção de suntuosos prédios administrativos e culturais, como os do Arquivo Público e o Teatro da Paz; e a instalação de um novo porto em estrutura de ferro importada da Europa.

De acordo com Penteado (1968) e Corrêa (1989), nessa fase já se identificava a diferenciação funcional dos dois bairros do CHB. Na Cidade Velha, área de ocupação mais antiga, caracterizada pelas ruas estreitas e pelos lotes de pequena dimensão, predominavam as atividades de apoio à navegação e à comercialização de produtos regionais, além da presença de instituições públicas e religiosas de grande porte. Na Campina, onde as ruas eram mais largas e os lotes de maior tamanho, estava a principal centralidade da cidade, com os estabelecimentos comerciais e de serviços mais sofisticados. Ressalte-se que, nos dois bairros, os usos terciários concentravam-se nas franjas da orla, enquanto o uso habitacional, ou ocupava a parte superior dos imóveis comerciais, ou se localizava na porção mais continental.

Na década de 1930, utilizando o discurso da "modernidade", o poder público municipal passou a incentivar o processo de verticalização no CHB. Para atrair o investidor imobiliário, concedeu lotes e criou regulamentos, dando início, conforme Lima (2015), às primeiras normativas de disciplinamento da produção imobiliária no CHB.

0 processo de verticalização teve início nas bordas do CHB e intensificou-se nos anos de 1950, quando, por meio da lei municipal n. 3.450/1956, foram estabelecidos como gabaritos mínimos: 12 pavimentos, na avenida 15 de Agosto; e 10 pavimentos na avenida Portugal, no boulevard Castilhos França e na rua João Alfredo. Todas essas ruas estão localizadas no bairro da Campina, que se consolidou, na época, como a área da cidade que 
abrigava os principais comércios varejistas, prédios de escritórios, consultórios, bancos e demais serviços.

Em meados dos anos 1960, o bairro da Cidade Velha já apresentava sinais de decadência física. No bairro da Campina, ampliava-se a substituição do uso habitacional pelos usos terciários, e estabelecimentos mais sofisticados surgiam nas bordas do CHB, mais especificamente no eixo da avenida Presidente Vargas, onde o processo de verticalização teve lugar (Penteado, 1968).

Nesse contexto, emergiu a preocupação com a preservação do patrimônio arquitetônico visto como ameaçado pelas adaptações e construções que estavam sendo realizadas para atender a demandas de adaptação dos imóveis do capital comercial e de produção residencial pelo imobiliário (Lima, 2015). Como resultado, no final dos anos 1970, a lei n. 7.119/1979 instituiu um conjunto de restrições no CHB que proibia o uso habitacional coletivo em parte do bairro da Campina. Mas, isso não foi suficiente para conter o processo de verticalização no CHB. Com base em dados apresentados por Oliveira (1992) e Corrêa (1989), observa-se que, no período de 1974 a 1986, a quantidade de prédios com mais de 4 pavimentos saltou de 16 para 67 unidades no $\mathrm{CHB}$, beneficiando-se dos financiamentos concedidos via SBPE/BNH. A ausência de prédios com mais de 4 pavimentos na Cidade Velha, apesar de a lei n. 7.119/1979 nele permitir a verticalização, denota o pouco interesse que esse bairro despertava na demanda e no grande capital imobiliário.

As limitações à atuação do capital imobiliário no CHB ampliaram-se, sobremaneira, a partir da década de 1990, quando, após 0 tombamento pela Lei Orgânica do Município de Belém, foi instituída a lei municipal n. 7.709/1994. Conhecida como Lei do Centro Histórico, essa lei restringiu as possibilidades de remembrar lotes e de substituir edificações existentes por imóveis novos. Além disso, diminuiu a altura permitida para os prédios e estabeleceu outros índices urbanísticos que dificultaram a intensificação da ocupação no CHB (Lima, 2015).

0 deslocamento das moradias de camadas de maior renda, assim como das atividades econômicas mais sofisticadas para áreas localizadas fora do $\mathrm{CHB}$, que já vinha ocorrendo desde os anos 1960, foi intensificado a partir dos anos 1990, para o que contribuíram: a ampliação do uso do automóvel; a falta e/ou insuficiência de investimentos públicos no centro; a disseminação de novos padrões de morar (condomínios e conjuntos habitacionais), de consumir (shopping centers, hipermercados, etc.); a que o centro tradicional não podia mais responder.

0 resultado desse processo foi um progressivo aumento da ociosidade imobiliária e da degradação física dos imóveis e espaços públicos do CHB (Mercês, Tourinho e Lobo, 2014). No bairro da Campina, o comércio popular varejista - controlado por redes de departamento voltadas para as camadas de menor renda e por comerciantes asiáticos - expandiu-se significativamente, juntamente com a ocupação dos espaços públicos por vendedores ambulantes. $\mathrm{Na}$ Cidade Velha, cresceram as ocupações irregulares em palafitas por população de baixa renda, avançando sobre o rio Guamá. Tal processo não foi mais intenso porque funções públicas, como a Prefeitura, a Assembleia Legislativa e outras relacionadas ao poder judiciário, 
lá continuaram e ampliaram o espaço ocupado usando antigos casarões.

Com o intuito de recuperar o $\mathrm{CHB}, 0$ poder público vem desenvolvendo ações de recuperação física desde a década de 1970, concentradas, sobretudo, nas áreas mais próximas da orla.

A partir dos anos 1990, novas funções culturais, de lazer e voltadas para o fomento do turismo foram inseridas no centro, como os complexos Estação das docas e o Feliz lusitânia. Além delas, registram-se várias intervenções físicas pontuais em espaços públicos, como as reformas do calçadão na avenida João Alfredo e da feira do Ver-o-Peso e a recuperação de diversos imóveis. Nesse segundo caso, estão as obras financiadas pelo Programa Monumenta e pelo Programa de Arrendamento Habitacional do Governo Federal, que converteram uma edificação de salas comerciais num prédio com 66 apartamentos. Ademais, ainda existem importantes vantagens locacionais que atraem moradores para o CHB (ibid.).

Da análise até aqui desenvolvida, nota-se que, da mesma forma que o CHR, o CHB não é homogêneo. Contudo, diferentemente do que ocorreu em alguns espaços do CHR, as ações implementadas no CHB não foram suficientes para reverter o processo mais amplo de degradação física nem para inserir esse centro em circuitos superiores da economia globalizada. Ao invés disso, tudo indica que é pela articulação do circuito inferior com o circuito superior marginal, usando imóveis antigos e barracas situadas em via públicas para a comercialização de artigos populares, importados principalmente de países asiáticos, legal ou ilegalmente, que se faz notar, da maneira mais evidente, a inserção do CHB na economia global.

\section{No Centro Histórico de São Luís}

Após um período de riqueza que levou, no século XIX, a ser vista como o quarto centro urbano do País, São Luís, nas primeiras décadas do século $\mathrm{XX}$, ingressou num período de estagnação econômica que, por um lado, inibiu ações mais vigorosas de renovação urbana por parte do poder público e, por outro, levou ao abandono dos casarões.

Na segunda metade do século $X X$, a visita de duas missões da Unesco - a de Michel Parent, em 1967, e a de Viana de Lima, em 1972 -, que reconhecerem o valor do sítio histórico de São Luís, foram fundamentais para o processo de conservação. Para ambas, a situação de destruição e de abandono se resolveria com a oportunidade que o patrimônio cultural representava para o turismo.

Ao mesmo tempo, na década de 1960, preparava-se o processo de recuperação da economia do Maranhão, tendo como alavanca o escoamento do minério de Carajás pelo porto de Itaqui. Prevendo-se um forte crescimento demográfico, tratou-se de preparar a cidade. Foi criado o distrito industrial e, nos anos 1970, consolidou-se a ocupação em direção às praias, via ponte do São Francisco e, em direção ao porto de Itaqui (inaugurado em 1971), pela barragem do Bacanga. Tudo isso foi reforçado por um sistema viário de amplas avenidas e pelo financiamento da casa própria, promovido pela construção de conjuntos habitacionais financiados pelo BNH nas novas áreas conquistadas.

Se, por um lado, o deslocamento dos novos investimentos aliviou as tensões de "renovação urbana" no centro, por outro lado, a criação de novas áreas residenciais levou, 
paulatinamente - como ocorreu no CHR e CHB - ao abandono da área central, inclusive no que diz respeito aos investimentos governamentais, o que contribuiu para a degradação das infraestruturas e das edificações.

A promoção de novas áreas residenciais exigia - e ainda exige - a desvalorização das áreas antigas como lugar de morar (Venancio, 2011). 0 próprio Plano Diretor de 1974 propunha a inibição do uso residencial no centro. Como consequência, a elite partiu para os novos espaços de maior prestígio social levando, muitas vezes também, os inquilinos a procurar outros espaços e os proprietários a preferir alugar seus imóveis para uso comercial. A cidade histórica, então, transformava-se em centro administrativo, comercial e de serviços, além de polo de atração do turismo cultural.

Nesse contexto, o governo de Estado tomou a si a responsabilidade da promoção da conservação do Patrimônio Histórico. Em outubro de 1979, teve início o Programa de Preservação e Revitalização do Centro Histórico de São Luís (PPRCHSL). Esse Programa, sob o comando de Luís Phellipe Andrès (1998), tinha como princípio a integração do patrimônio histórico no processo de desenvolvimento do estado do Maranhão, seu aproveitamento como atração turística e cultural e a recuperação das infraestruturas como alavanca da revitalização, incluindo-se tão somente os prédios mais importantes.

A primeira etapa do PPRCHSL foi realizada entre 1981 e 1982 e, dentre outros, recuperou, mediante reforma e ampliação, a feira da Praia Grande. Em 1987, aconteceu o projeto Reviver. Reconstruíram-se espaços públicos destruídos ou deteriorados, como o Largo do Comércio. Construíram-se novas praças nos antigos terrenos baldios. Colocou-se nova iluminação pública, subterrânea. As calçadas de cantaria foram restituídas a suas dimensões originais. As escadarias foram recuperadas e construídas novas. A área da Praia Grande passou a ser exclusivamente reservada para pedestres. Além disso, o Projeto Reviver abrangeu obras de reabilitação de várias edificações. 0 Centro Histórico de São Luís estava consagrado. ${ }^{3}$

O PPRCHSL permaneceu ativo por mais de 25 anos, sob o comando do governo do estado do Maranhão, com recursos de bancos internacionais, programas federais e estaduais. Liderou o processo de inclusão na Lista do Patrimônio Mundial da Unesco e provocou a instalação da Superintendência do Patrimônio Histórico de São Luís em 1987.

Nos solares e casarões, instalaram-se órgãos públicos de todos os níveis: centros culturais, de criatividade e profissionalizantes; diversas instituições de ensino, dentre outras. Ao mesmo tempo, estimulou-se a permanência da população existente e promoveu-se a vinda de novas atividades, como as de lazer (Souza, 1999). Importa acrescentar que o selo patrimônio da humanidade garantia a inclusão de São Luís na rota do turismo cultural.

De todas as ações do PPRCHSL, merece destaque o Programa de Habitação. Em 1995, aconteceu o Projeto Piloto de Habitação na área da Praia Grande. De forma audaciosa e única, o programa recuperou um casarão ocupado, um cortiço, mantendo os moradores no local. Esse Programa foi retomado nos anos 2000 em duas frentes. Na primeira, a Casa dos Artistas, antigos galpões industriais foram reabilitados para uso misto por artistas locais, ficando o ateliê no primeiro andar e a 
residência no segundo. A segunda, idealizada pelo estado, recuperou sete prédios com finalidade habitacional. Os apartamentos foram disponibilizados em forma de leasing para funcionários do estado.

Requalificado o centro histórico, o patrimônio cultural da humanidade recuperou o seu valor histórico e conseguiu integrar-se à cidade contemporânea como centro cultural, como objeto do turismo e de visitação (Venancio, 2009). Entretanto, essa condição não levou à sua reocupação como lugar residencial, embora muitos dos antigos moradores ali permaneçam. A expansão para a orla gerou novas centralidades que atraíram para si, não apenas moradores, mas serviços e comércio.

Nos anos 2000, a própria prefeitura passou a se ocupar mais diretamente do Centro Histórico, empurrada e estimulada pela condição de Patrimônio da Humanidade, apoiada, inclusive pela União.

Tão logo foi criado, o Ministério das Cidades elegeu como uma de suas prioridades a reabilitação de Centros Urbanos, o que, por si só, mostra a importância que era dada naquele momento aos centros urbanos e à sua reabilitação. São Luís foi uma das cidades "patrimônio da humanidade" (ao lado de Salvador e Olinda) apoiadas pelo Programa de Reabilitação de Áreas Urbanas Centrais. Em todas as cidades, o governo federal buscava articular "o apoio à elaboração de planos integrados de reabilitação com a atribuição dos recursos para moradia, por meio de vários programas da Secretaria Nacional de Habitação e do Ministério das Cidades, operacionalizados pela Caixa e em colaboração estreita com as iniciativas coordenadas pelo programa Monumenta" (Ministério das Cidades, 2008, p. 55).
Em tal contexto, e contando ainda com a colaboração espanhola, mediante um convênio da junta de Andaluzia com o Ministério das Cidades e a municipalidade, foi elaborado o Plano Municipal de Gestão do Centro Histórico de São Luís, priorizando a área do Desterro, buscando manter os moradores existentes e atrair novos usuários e investimentos.

Seguem-se os passos do PPRCHSL, embora tenha se invertido a ênfase dos investimentos que agora não priorizam mais a reabilitação das infraestruturas, o que constitui um grave problema, especialmente porque não apenas ruas e calçadas necessitam de manutenção, mas porque o fornecimento de água e de eletricidade não atende às necessidades básicas da área. Ressalte-se que as 44 ações previstas - que contemplam igrejas, fortaleza, estação ferroviária, monumentos, praças e imóveis - seguem o mesmo objetivo de recuperar o conjunto do CHSL para o uso contemporâneo, acreditando que as ações governamentais vão conseguir atrair investimentos dos setores privados, especialmente dos setores de educação, cultura e turismo. A despeito dos investimentos e das ações de recuperação que se vão processando (ainda não completas), o abandono das edificações persiste, atingindo agora, também, o setor comercial.

\section{Submercado de imóveis habitacionais}

O objetivo desta seção é analisar a evolução do submercado de imóveis residenciais, procurando identificar as semelhanças e as diferenças observadas entre os centros históricos e no interior de cada centro estudado. 
Tabela 1 - Número de domicílios particulares permanentes

(1991-2010)

\begin{tabular}{l|r|r|r|r}
\hline \multicolumn{1}{c|}{ Local } & 1991 & 2010 & Var. Abs. & Var. (\%) \\
\hline CH Recife (A) & 5.214 & 5.111 & -103 & $-2,0$ \\
Cidade do Recife (B) & 311.365 & 477.166 & 165.801 & 53,2 \\
(A) / (B) (\%) & 1,7 & 1,1 & - & - \\
\hline CH São Luís (C) & 2.494 & 2.056 & -438 & $-17,6$ \\
Cidade de São Luís (D) & 140.662 & 276.812 & 136.190 & - \\
(C) / (D) (\%) & 1,8 & 0,7 & 1.089 & 50,8 \\
\hline CH Belém (E) & 2.160 & 3.249 & 112.975 & 44,1 \\
Cidade de Belém (F) & 255.902 & 368.877 & - & - \\
(E) / (F) (\%) & 0,8 & 0,9 & & - \\
\hline
\end{tabular}

Fonte: IBGE, Censos de 1991 e 2010.

A Tabela 1 mostra que houve redução de domicílios no CHR e no CHSL no período 1991-2010, distintamente do que ocorreu no conjunto de cada cidade onde estão esses dois centros e, no $\mathrm{CHB}$, onde a quantidade de domicílios foi acrescida.

No CHR, tal redução se deveu à substituição do uso habitacional por usos de comércio e serviços, fenômeno que ocorreu com mais força nos bairros do Recife e de Santo Antônio. Como visto anteriormente, ambos os bairros conheceram processos relativamente mais acentuados de intervenções urbanísticas. Ademais, eles vêm sendo adaptados, nos últimos 20 anos, de modo a proporcionar, respectivamente, 0 desenvolvimento de atividades de TIC, aliadas às de lazer e turismo e de ensino universitário. Trata-se de um exemplo em que a inserção na economia globalizada vem promovendo importantes alterações no perfil dos usos do solo.
0 mesmo processo de substituição do uso habitacional pelos usos comercial e de serviços pode ser alegado para explicar a perda de domicílios no CHSL; nesse caso, mais especificamente, em decorrência do forte crescimento do turismo.

Ao contrário dos outros dois centros históricos, o de Belém experimentou um significativo incremento de 1.089 domicílios, num percentual maior, inclusive, do que o registrado para o conjunto da cidade de Belém. Trata-se de um número relevante, considerando-se os verificados no CHR e no CHSL, assim como o longo processo de degradação do espaço construído do CHB. De um lado, a demanda dos imigrantes asiáticos por imóveis e, e, do outro, o agravamento do problema de mobilidade - que torna a proximidade casa-trabalho e/ou casa-compras uma vantagem locacional de grande importância - são alguns dos fatores 
Tabela 2 - População residente em domicílios particulares permanentes

(1991-2010)

\begin{tabular}{l|r|r|r|c}
\hline \multicolumn{1}{c|}{ Local } & \multicolumn{1}{c|}{1991} & 2010 & Var. Abs. & Var. (\%) \\
\hline CH Recife (A) & 13.836 & 12.301 & -1.535 & $-11,1$ \\
Cidade do Recife (B) & 1.298 .229 & 1.537 .704 & 239.475 & 18,4 \\
(A) / (B) (\%) & 1,1 & 0,8 & - & - \\
\hline CH São Luís (C) & 10.578 & 6.679 & -3.899 & $-36,9$ \\
Cidade de São Luís (D) & 692.440 & 1.014 .837 & 322.397 & 46,6 \\
(C) / (D) (\%) & 1,5 & 0,7 & - & - \\
\hline CH Belém (E) & 9.140 & 10.817 & 1.677 & 18,3 \\
Cidade de Belém (F) & 1.244 .689 & 1.393 .399 & 148.710 & 12,0 \\
(E) / (F) (\%) & 0,7 & 0,8 & - & - \\
\hline
\end{tabular}

Fonte: IBGE, Censos de 1991 e 2010.

explicativos desse comportamento. Internamente, no $\mathrm{CHB}$, o crescimento mais intenso acontesceu no bairro da Cidade Velha, onde a concorrência com outros usos era menos expressiva. No bairro da Campina, as transações imobiliárias deram-se, muito mais, no mercado de imóveis comerciais e de serviços. Dentre os imóveis ocupados por esse segmento, destacam-se os destinados à comercialização de mercadorias populares, importadas de países asiáticos, de baixo preço e, em geral, de baixa qualidade. Tais imóveis são usados para venda direta ao consumidor, como depósitos de mercadorias para abastecer ambulantes ou ambos.

A Tabela 2 apresenta a evolução da população residente nos três centros históricos. Em consonância com a forma como evoluiu o número de domicílios no período 1991-2010, houve um decréscimo de residentes nos CHSL e no CHR e aumento no CHB. Observa-se, contudo, que, comparando-se os percentuais das Tabelas 1 e 2, o decréscimo percentual de população nos dois primeiros foi bem maior do que a queda do número de domicílios, respectivamente. Além disso, o aumento relativo do número de domicílios em Belém foi bem superior ao incremento de moradores. Em termos aritméticos, isso se justifica pela queda da média de pessoas por domicílios que aconteceu nos três centros históricos no período, fenômeno que também teve lugar nos municípios que sediam esses centros.

A queda dessa média é, na verdade, um fenômeno generalizado no Brasil (4,19 para 3,31 pessoas por domicílio). Alves e Cavenaghi (2012) defendem que as principais causas dessa redução sejam: o envelhecimento da população; a diversificação dos arranjos familiares; o aumento do número de pessoas que moram sozinhas; o crescimento do número de casais sem filhos; o incremento das famílias monoparentais; e a tendência à diminuição da participação percentual da família tradicional formada por casal com um ou mais filhos. 
Tabela 3 - População residente em domicílios particulares permanentes por número de moradores (1991-2010)

\begin{tabular}{|c|c|c|c|c|c|c|}
\hline Local & 1991 & Part. (\%) & 2010 & Part. (\%) & Var. Abs. & Var. (\%) \\
\hline \multicolumn{7}{|l|}{1 a 2 moradores } \\
\hline CH Recife & 2.053 & 49,2 & 2.921 & 61,8 & 868 & 42,3 \\
\hline Cidade do Recife & 66.731 & 21,8 & 166.891 & 35,5 & 100.160 & 150,1 \\
\hline CH São Luís & 583 & 23,4 & 877 & 42,7 & 294 & 50,4 \\
\hline Cidade de São Luís & 34.624 & 24,6 & 77.328 & 27,9 & 42.704 & 123,3 \\
\hline CH Belém & 611 & 28,1 & 1.796 & 34,9 & 1.185 & 193,9 \\
\hline Cidade de Belém & 58.029 & 19,7 & 98.876 & 26,8 & 40.847 & 70,4 \\
\hline \multicolumn{7}{|l|}{3 e mais moradores } \\
\hline CH Recife & 2.122 & 50,8 & 1.803 & 38,2 & -319 & $-15,0$ \\
\hline Cidade do Recife & 239.882 & 78,2 & 303.579 & 64,5 & 63.697 & 26,6 \\
\hline CH São Luís & 1.911 & 76,6 & 1.179 & 57,3 & -372 & $-38,3$ \\
\hline Cidade de São Luís & 105.998 & 75,4 & 199.484 & 72,1 & 93.486 & 88,2 \\
\hline CH Belém & 1.564 & 71,9 & 3.355 & 65,1 & 1.791 & 114,5 \\
\hline Cidade de Belém & 236.947 & 80,3 & 270.001 & 73,2 & 33.054 & 13,9 \\
\hline
\end{tabular}

Fonte: IBGE, Censos de 1991 e 2010.

Os autores também mencionam a influência do aumento mais acelerado do estoque de domicílios em relação ao crescimento populacional, do incremento da taxa de chefia - isto é, o percentual provável de adultos capazes de formar um domicílio autônomo -, que se torna maior à medida que aumenta a faixa etária da adolescência para a vida adulta. Tais transformações em curso no Brasil são particularmente importantes nos centros históricos, locais onde, aparentemente, vêm sendo mais intensas, já que as médias de pessoas por domicílios em 2010, nos três centros estudados, foram menores do que as das cidades em que se localizam.

A influência dessas dinâmicas no mercado imobiliário habitacional das três áreas centrais pode ser percebida com mais detalhes a partir da análise da Tabela 3. No CHR, no CHB e no CHSL, os percentuais da população que residia em domicílios com até dois moradores, em 1991, evoluíram positivamente em 2010, sugerindo que houve, no período, o incremento de arranjos familiares diferentes da família tradicional composta por três ou mais moradores. Nota-se, também, a presença mais intensa de famílias com perfil tradicional no CHSL e no CHB do que no CHR. Neste último, aliás, os domicílios com até dois moradores, em 1991, já eram bem mais expressivos do que nos outros dois centros.

No caso do CHR, os dados facultam inferir que São José e Boa Vista constituem os locais mais procurados por pessoas solteiras ou casais sem filhos que, na sua grande maioria, 
Tabela 4 - Domicílios particulares permanentes vagos

(2010)

\begin{tabular}{l|r|c}
\hline \multicolumn{1}{c|}{ Cidade / Bairro } & \multicolumn{1}{c|}{ No $^{\text {( }}$} & Perc. (\%) \\
\hline Campina & 473 & 17,6 \\
Cidade Velha & 323 & 9,2 \\
Subtotal & 796 & 14,2 \\
Cidade de Belém & 35.173 & 8,3 \\
Boa Vista & 820 & 11,3 \\
Recife & 11 & 5,1 \\
Santo Antônio & 89 & 36,3 \\
São José & 453 & 13,8 \\
Subtotal & 1.373 & 13,7 \\
Cidade do Recife & 34.411 & 6,7 \\
\hline
\end{tabular}

Fonte: IBGE, Censos de 1991 e 2010.

chegam ao Recife para realizar atividades de estudo e tratamento médico, dentre outras. Trata-se daquelas "pessoas apressadas", ou "forasteiros", mencionados por Bernardino e Lacerda (2015). No CHB, o percentual de moradias com mais de dois habitantes é bem mais elevado na Cidade Velha do que na Campina, o que pode ser explicado pela presença mais forte de apartamentos no segundo bairro.

Outro aspecto importante para a caracterização do mercado imobiliário de um local é o número absoluto e o percentual de domicílios vagos, posto que é um indicador de oferta (real ou potencial). A Tabela 4 apresenta os dados da ociosidade imobiliária nos bairros que integram, total ou parcialmente, os centros históricos de Belém e Recife em 2010. Os dados nela contidos são fornecidos pelo IBGE, que utiliza o bairro como unidade espacial. A inexistência de bairros reconhecidos pelo IBGE impossibilitou a análise do CHSL, e a não coincidência dos limites dos bairros com os dos CHR e CHR requer que se alerte para a necessidade de relativização das análises a seguir.

A Tabela 4 mostra que, embora no conjunto de bairros as duas cidades possuam percentuais totais semelhantes de domicílios vagos, tais percentuais são bastante díspares entre os bairros, o que expressa as distintas dinâmicas socioeconômicas existentes em cada centro. A Tabela 4 também revela que os percentuais de domicílios vagos nos bairros que integram o CHR e o CHB são bem maiores que os totais das cidades onde estão situados. Uma hipótese explicativa para isso consiste no fato de o estoque imobiliário dos centros históricos ser constituído, em termos relativos, por edificações mais antigas do que o do resto da cidade. Como consequência, é de se supor que apresente percentual maior de imóveis em ruínas e/ou com dificuldades adicionais para serem conservados e adaptados aos requisitos da vida moderna exigidos pela demanda. 
Tabela 5 - Tipologia dos domicílios particulares permanentes

(1991-2010)

\begin{tabular}{|c|c|c|c|c|c|c|}
\hline Local & 1991 & Part. (\%) & 2010 & Part. (\%) & Var. Abs. & Var. (\%) \\
\hline \multicolumn{7}{|l|}{ Casa } \\
\hline CH Recife & 1.188 & 28,8 & $1.088^{1}$ & $23,6^{2}$ & -100 & $-8,4$ \\
\hline Cidade do Recife & 241.599 & 79,0 & 342.378 & 72,7 & 100.779 & 41,7 \\
\hline CH São Luís & 2.266 & 90,9 & 1.864 & 90,7 & -402 & $-17,7$ \\
\hline Cidade de São Luís & 133.954 & 95,0 & 246.260 & 89,0 & 112.306 & 83,8 \\
\hline CH Belém & 1.299 & 60,1 & 1.583 & 48,7 & 284 & 21,9 \\
\hline Cidade de Belém & 231.114 & 91,6 & 294.491 & 87,8 & 63.377 & 27,4 \\
\hline \multicolumn{7}{|l|}{ Apartamento } \\
\hline CH Recife & 2.922 & 70,8 & $3.521^{1}$ & $76,4^{2}$ & 599 & 20,5 \\
\hline Cidade do Recife & 63.096 & 20,6 & 124.355 & 26,4 & 61.259 & 97,1 \\
\hline CH São Luís & 167 & 6,7 & 134 & 6,5 & -33 & $-19,8$ \\
\hline Cidade de São Luís & 5.591 & 4,0 & 24.910 & 9,0 & 19.319 & 345,5 \\
\hline CH Belém & 858 & 39,7 & 1.656 & 51,0 & 798 & 93,0 \\
\hline Cidade de Belém & 21.161 & 8,4 & 40.912 & 12,2 & 19.751 & 93,3 \\
\hline \multicolumn{7}{|l|}{ Cômodo } \\
\hline CH Recife & 15 & 0,4 & $x$ & $x$ & - & - \\
\hline Cidade do Recife & 1.206 & 0,4 & 4.021 & 0,9 & 2.815 & 233,4 \\
\hline CH São Luís & 61 & 2,4 & 58 & 2,8 & -3 & $-4,9$ \\
\hline Cidade de São Luís & 1.437 & 1,0 & 5.642 & 2,0 & 4.205 & 292,6 \\
\hline CH Belém & 3 & 0,1 & 10 & 0,3 & 9 & 200,0 \\
\hline Cidade de Belém & 3.627 & 1,4 & 2.481 & 0,7 & -1.146 & $-31,6$ \\
\hline
\end{tabular}

Fonte: IBGE. Censos de 1991 e 2010.

${ }^{1}$ Exclusive a parte do bairro do Recife situada no CHR.

2 Exclusive os cômodos.

Nota: a fonte não fornece, em 2010, os dados acerca da tipologia das edificações dos domicílios particulares permanentes para os setores censitários que compõem o Bairro do Recife, nem os dados referentes aos domicílios do tipo cômodo para todos os setores que compõem o CHR.

No que concerne à tipologia dos domicílios, a Tabela 5 mostra, com base em dados do Censo Demográfico de 2010, realidades distintas. Enquanto a casa é a tipologia largamente dominante no CHSL, os apartamentos detêm a supremacia no CHR, e há uma situação equilibrada entre casas e apartamentos no CHB. Tais números refletem as diferentes formas com que os três centros históricos foram o palco de processos de verticalização: fortemente restrito em São Luís; de forma intensa em Recife, especialmente no bairro da Boa Vista; e moderado em Belém, onde ficou praticamente concentrado nas bordas do bairro da Campina.

No período 1991-2010, as alterações na tipologia domiciliar foram pequenas ou moderadas nos três centros históricos. A única exceção foi verificada em Belém, onde cresceu o número de apartamentos. A legislação preservacionista pode ser apontada como 0 
Tabela 6 - Condição de ocupação dos domicílios particulares permanentes (1991-2010)

\begin{tabular}{|c|c|c|c|c|c|c|}
\hline Local & 1991 & Part. (\%) & 2010 & Part. (\%) & Var. Abs. & Var. (\%) \\
\hline \multicolumn{7}{|l|}{ Próprio } \\
\hline CH Recife & 1.822 & 44,2 & 2.381 & 50,4 & 559 & 30,7 \\
\hline Cidade do Recife & 227.601 & 74,4 & 343.914 & 73,1 & 116.313 & 51,1 \\
\hline CH São Luís & 1.745 & 70,0 & 1.362 & 66,2 & -383 & $-21,9$ \\
\hline Cidade de São Luís & 118.918 & 84,6 & 217.161 & 78,5 & 98.243 & 82,6 \\
\hline CH Belém & 1.261 & 58,4 & 1.929 & 59,4 & 668 & 53,0 \\
\hline Cidade de Belém & 208.483 & 81,5 & 291.788 & 79,1 & 83.305 & 40,0 \\
\hline \multicolumn{7}{|l|}{ Alugado } \\
\hline CH Recife & 2.127 & 51,6 & 2.181 & 46,1 & 54 & 2,5 \\
\hline Cidade do Recife & 62.427 & 20,4 & 104.621 & 22,2 & 42.194 & 67,6 \\
\hline CH São Luís & 640 & 25,7 & 577 & 28,1 & -63 & $-9,8$ \\
\hline Cidade de São Luís & 15.337 & 10,9 & 50.335 & 18,2 & 34.998 & 228,2 \\
\hline CH Belém & 777 & 36,0 & 1.177 & 36,2 & 400 & 51,5 \\
\hline Cidade de Belém & 35.664 & 13,9 & 60.154 & 16,3 & 24.490 & 68,7 \\
\hline \multicolumn{7}{|l|}{ Cedido e outra condição } \\
\hline CH Recife & 161 & 3,9 & 144 & 3,0 & -17 & $-10,6$ \\
\hline Cidade do Recife & 13.591 & 4,4 & 18.606 & 4,0 & 5.015 & 36,9 \\
\hline CH São Luís & 109 & 4,4 & 117 & 5,7 & 8 & 7,3 \\
\hline Cidade de São Luís & 6.367 & 4,5 & 9.316 & 3,4 & 2.949 & 46,3 \\
\hline CH Belém & 122 & 5,6 & 143 & 4,4 & 21 & 17,2 \\
\hline Cidade de Belém & 11.755 & 4,6 & 16.935 & 4,6 & 5.180 & 44,1 \\
\hline
\end{tabular}

Fonte: IBGE, Censos de 1991 e 2010.

principal motivo para as reduzidas transformações. No caso do forte incremento do percentual de apartamentos em Belém, onde não houve construção de novos edifícios no CHB, pode-se sugerir que esse resultado tenha sido influenciado pela conversão de salas comerciais em apartamentos, anteriormente mencionada, e pela reocupação de apartamentos que haviam sido abandonados pelas camadas de maior renda no corredor da avenida Presidente Vargas. Uma característica positiva comum aos três centros históricos é a inexpressiva presença de cômodos.
Em relação à condição de ocupação, a Tabela 6 mostra que o percentual de domicílios alugados no CHR é bem superior aos do CHB e do CHSL, o que evidencia um maior dinamismo do mercado imobiliário residencial rentista no centro histórico da capital pernambucana do que nos outros dois. A presença marcante de residências das "pessoas apressadas", já referenciada anteriormente, contribui decisivamente para esse resultado. Já no CHSL, ao contrário, a estabilidade da residência dos moradores é bem maior, a julgar pelo elevado percentual de domicílios próprios. 
Uma característica comum a ser realçada nos três centros históricos é que os percentuais de domicílios alugados é bem maior que os observados quando considerados os conjuntos das cidades onde estão situados. Em 2010, tal percentual chegou a ser mais do que o dobro em Recife e em Belém. Em São Luís, essa diferença é menor, mas não menos importante. Isso demonstra que os imóveis nos centros históricos ainda se constituem em opção de investimento e/ou de reserva de valor. É interessante notar que, no período 1991-2010, o percentual de domicílios próprios em relação ao total cresceu no CHR, decresceu no CHSL e permaneceu estável no CHB. Já os imóveis cedidos ou em outra condição de ocupação tiveram reduzida presença nos três centros históricos.

\section{Mercado de compra e venda de imóveis}

Para que se reproduza ou se altere a divisão Econômica e Social do Espaço (Dese), é necessário um mecanismo regulador que, de acordo com Lipietz (1974), é o tributo fundiário ${ }^{4}$ (a renda do solo). Para ele, há dois tipos desse tributo: um exógeno e o outro endógeno. 0 primeiro tem seu nível determinado pelas características da situação social do terreno. 0 segundo depende do montante de capital suscetível de ser investido no terreno, durante o seu processo produtivo, o que está sujeito à legislação urbanística e, mais especificamente, ao coeficiente de utilização do terreno.

Como nas áreas históricas, os bens imobiliários na sua quase totalidade são vendidos com seu suporte (o terreno), o tributo fundiário insere-se no preço de mercado das edificações. Ora, acontece que o coeficiente de utilização nos centros históricos é, em geral, único em todo o território. Isso descartaria, inteiramente ou quase totalmente, a existência de um tributo endógeno. Portanto, o que está em jogo é, notadamente, o tributo exógeno, que pode tão só reproduzir, via herança histórica, partes da Dese - como ocorre, notadamente, em partes dos bairros de São José e da Boa Vista, no CHR, e nos bairros do CHB - e/ou transformar outras, por meio de investimentos capitaneados pelo Estado - situação do Bairro do Recife (CHR) e partes importantes do (CHSL) -, ou pelo setor privado - fato mais recente, no bairro de Santo Antônio (CHR). Tais movimentos revelam as diferentes estratégias dos agentes econômicos e do Estado, o que se traduz no preço das transações imobiliárias (Lacerda e Fernandes, 2015).

Como não foi possível enfocar a dinâmica dos preços dos imóveis referentes aos três centros históricos, optou-se por analisar essa dinâmica por meio da quantidade das transações imobiliárias realizadas entre 2008 e 2013. ${ }^{5}$ Inicia-se com o caso do CHR, cujo exame teve, como fundamento, os estudos realizados por Lacerda e Anjos (2015) e por Lacerda e Fernandes (2015).

Os dados da Tabela 7 reforçam a ideia de que o mercado habitacional praticamente inexiste nos bairros do Recife e de Santo Antônio. Das 56 transações de compra e venda realizadas no bairro do Recife, apenas uma correspondeu a residência. Das 482 refentes ao bairro de Santo Antônio apenas 13 concerniam a habitação, e parte substancial das transações ocorreu em 2013, como resultado da aceleração dos investimentos privados em recuperação de imóveis para fins educacionais. 
Tabela 7 - Imóveis transacionados por compra e venda por ano, CHR (2008-2013) ${ }^{1}$

\begin{tabular}{r|l|r|r|r|r|r|r|r}
\hline Uso & \multicolumn{1}{|c|}{ Bairros } & 2008 & 2009 & 2010 & 2011 & 2012 & 2013 & Total \\
\hline \multirow{5}{*}{ Comercial } & Recife & 8 & 9 & 5 & 13 & 13 & 7 & 55 \\
& São José & 12 & 16 & 18 & 24 & 19 & 12 & 101 \\
& Santo Antônio & 72 & 65 & 84 & 71 & 74 & 103 & 469 \\
& Boa Vista & 81 & 67 & 84 & 58 & 71 & 55 & 416 \\
& Subtotal & 173 & 157 & 191 & 166 & 177 & 177 & 1041 \\
\hline \multirow{5}{*}{ Residencial } & Recife & 0 & 0 & 0 & 1 & 0 & 0 & 1 \\
& São José & 5 & 5 & 9 & 15 & 40 & 22 & 96 \\
& Santo Antônio & 1 & 4 & 2 & 5 & 1 & 0 & 13 \\
& Boa Vista & 96 & 85 & 90 & 90 & 90 & 57 & 508 \\
& Subtotal & 102 & 94 & 101 & 111 & 131 & 79 & 618 \\
\hline
\end{tabular}

Fonte: Transações de Compra e Venda ITBI / PCR.

${ }^{1}$ Dados referentes ao ITBI cobrado entre janeiro de 2008 e outubro de 2013.

A Tabela 8 permite aprofundar a análise da dinâmica espacial no CHR, pois mostra a relação entre o número total de endereços (residência, comércio e serviços) e a quantidade de transações de compra e venda, conforme o uso. Verifica-se que, do total de endereços, $14,4 \%$ foram transacionados, sendo que, no bairro de Santo Antônio, nos últimos seis anos, foi comprado o equivalente a $32,8 \%$ do total dos seus endereços. Essa dinâmica relativamente alta se explica pelo aludido processo de atração de investimentos privados, sobretudo no que se refere aos serviços educacionais (ensino superior).

Em contrapartida, a relação entre o número de endereços existentes nos demais bairros e o total das respectivas transações foi apenas de 13,6\% na Boa Vista, 8,5\% no Recife e 7,7\% em São José. Na Boa Vista, foram negociados $10 \%$ do estoque habitacional e $24,2 \%$ do estoque comercial e de serviços da área. Todavia, a dinâmica das transações relativas a essas duas últimas atividades reproduz a espacialidade existente, ao invés de representar mudanças em termos de recuperação dos imóveis e de qualidade do espaço público.

Quanto ao bairro do Recife - onde ocorreram apenas 56 transações de compra e venda -, o processo de revitalização, capitaneado pelo Estado e iniciado na segunda metade dos anos de 1990, incentivou o mercado imobiliário nos anos subsequentes, quando muitos imóveis foram vendidos a empresas de TIC. Revela isso o papel "coordenador" do estado nas modificações desse território e, por extensão, na Dese do CHR. 
Tabela 8 - Transações de compra e venda - ITBI, CHR (2008-2013) ${ }^{1}$

\begin{tabular}{|c|c|c|c|c|c|c|c|c|c|c|c|c|}
\hline \multirow{3}{*}{$\begin{array}{c}\text { Área } \\
\text { de estudo }\end{array}$} & \multicolumn{4}{|c|}{ Total } & \multicolumn{4}{|c|}{ Residencial } & \multicolumn{4}{|c|}{ Comercial / Serviços } \\
\hline & \multicolumn{2}{|c|}{$\mathrm{N}^{\circ}$ Ender. [2] } & \multicolumn{2}{|c|}{ Compra e Venda } & \multicolumn{2}{|c|}{$\mathrm{N}^{\circ}$ Ender. [2] } & \multicolumn{2}{|c|}{ Compra e Venda } & \multicolumn{2}{|c|}{$\mathrm{N}^{\circ}$ Ender. [2] } & \multicolumn{2}{|c|}{ Compra e Venda } \\
\hline & Abs. & $\%$ & Abs. & $\%$ & Abs. & $\%$ & Abs. & $\%$ & Abs. & $\%$ & Abs. & $\%$ \\
\hline Recife & 660 & 100 & 56 & 8,5 & 218 & 33,0 & 1 & 0,5 & 442 & 66,0 & 55 & 12,4 \\
\hline São José & 2556 & 100 & 197 & 7,7 & 978 & 38,3 & 96 & 9,8 & 1578 & 61,7 & 101 & 6,4 \\
\hline Santo Antônio & 1470 & 100 & 482 & 32,8 & 245 & 16,7 & 13 & 5,3 & 1225 & 83,3 & 469 & 38,3 \\
\hline Boa Vista & 6812 & 100 & 924 & 13,6 & 5090 & 74,7 & 508 & 10,0 & 1722 & 25,3 & 416 & 24,2 \\
\hline Total & 11498 & 100 & 1659 & 14,4 & 6531 & 56,8 & 618 & 9,46 & 4967 & 43,2 & 1041 & 21,0 \\
\hline
\end{tabular}

Fonte: Cadastro Nacional de Endereços para Fins Estatísticos (IBGE, 2010); Transações de Compra e Venda ITBI/PCR.

${ }^{1}$ Dados referentes ao ITBI cobrado entre janeiro de 2008 e outubro de 2013.

2 Foram excluídas do universo de endereços as edificações caracterizadas como "em construção".

Tabela 9 - Imóveis transacionados por compra e venda por ano, CHB (2008-2013) ${ }^{1}$

\begin{tabular}{|c|c|c|c|c|c|c|c|c|}
\hline Uso & Bairros & 2008 & 2009 & 2010 & 2011 & 2012 & 2013 & Total \\
\hline \multirow{3}{*}{ Comercial } & Campina & 53 & 44 & 46 & 123 & 91 & 45 & 402 \\
\hline & Cidade Velha ${ }^{2}$ & 4 & 3 & 7 & 4 & 7 & 4 & 29 \\
\hline & Subtotal & 57 & 47 & 53 & 127 & 98 & 49 & 431 \\
\hline \multirow{3}{*}{ Residencial } & Campina & 74 & 66 & 58 & 78 & 89 & 39 & 404 \\
\hline & Cidade Velha ${ }^{2}$ & 23 & 19 & 22 & 18 & 22 & 9 & 113 \\
\hline & Subtotal & 97 & 85 & 80 & 96 & 111 & 48 & 517 \\
\hline \multicolumn{2}{|r|}{ Total } & 154 & 132 & 133 & 223 & 209 & 97 & 948 \\
\hline
\end{tabular}

Fonte: Prefeitura Municipal de Belém.

1 Dados referentes ao ITBI cobrado entre janeiro de 2008 e outubro de 2013.

2 Dados correspondentes à parte do bairro que está inserida no CHB.

No Bairro de São José, diferentemente dos demais do CHR, além do menor dinamismo do mercado de compra e venda, as transações relativas à habitação representaram $9,8 \%$ do estoque residencial e $6,4 \%$ do referente às atividades comerciais e de serviços. Trata-se, conforme já ressaltado, de herança histórica, que vem se reproduzindo espacialmente por meio dos mercados de locação e de compra e venda.
No CHB, foram transacionados 948 imóveis entre janeiro de 2008 e outubro de 2013 (Tabela 9). 0 maior número de transações ocorreu no ano 2011, notando-se uma queda significativa em 2013, mesmo ao se considera que os dados desse ano contemplam apenas o período janeiro-outubro. Desse total, $54,5 \%$ eram residenciais e $45,5 \%$ comerciais, o que é uma evidência da vitalidade do uso habitacional na área. 
Tabela 10 - Transações de compra e venda - ITBI, CHB (2008 - 2013) ${ }^{1}$

\begin{tabular}{|c|c|c|c|c|c|c|c|c|c|c|c|c|}
\hline \multirow{3}{*}{$\begin{array}{c}\text { Área } \\
\text { de estudo }\end{array}$} & \multicolumn{4}{|c|}{ Total } & \multicolumn{4}{|c|}{ Residencial } & \multicolumn{4}{|c|}{ Comercial / Serviços } \\
\hline & \multicolumn{2}{|c|}{$\mathrm{N}^{\circ}$ End. $^{2}$} & \multicolumn{2}{|c|}{ Compra e Venda } & \multicolumn{2}{|c|}{$N^{\circ}$ End. $^{2}$} & \multicolumn{2}{|c|}{ Compra e Venda } & \multicolumn{2}{|c|}{$\mathrm{N}^{\circ}$ End. $^{2}$} & \multicolumn{2}{|c|}{ Compra e Venda } \\
\hline & Abs. & $\%$ & Abs. & $\%$ & Abs. & $\%$ & Abs. & $\%$ & Abs. & $\%$ & Abs. & $\%$ \\
\hline Campina & 4825 & 100 & 806 & 16,7 & 2661 & 55,2 & 404 & 15,2 & 2164 & 44,9 & 402 & 18,6 \\
\hline Cidade Velha ${ }^{3}$ & 1723 & 100 & 142 & 8,2 & 1220 & 70,8 & 113 & 9,3 & 503 & 29,2 & 29 & 5,8 \\
\hline Total & 6548 & 100 & 948 & 14,5 & 3881 & 59,3 & 517 & 13,3 & 2667 & 40,7 & 431 & 16,2 \\
\hline
\end{tabular}

Fonte: Cadastro Nacional de Endereços para Fins Estatísticos - CNEFE (IBGE, 2010); Transações de Compra e Venda ITBI /Sefin

${ }^{1}$ Dados referentes ao ITBI cobrado entre janeiro de 2008 e outubro de 2013.

2 Foram excluídas do universo de endereços as edificações caracterizadas como "em construção".

${ }^{3}$ Dados correspondentes à parte do bairro que está inserida no CHB.

0 mercado imobiliário de compra e venda de imóveis comerciais e de serviços mostrou-se, no CHB, menos dinâmico que o do CHR: foram transacionados $16,2 \%$ dos imóveis existentes (Tabela 10), em comparação aos $21 \%$ do CHR. Trata-se de um resultado esperado, considerando-se o quadro de degradação física do espaço construído do centro histórico da capital paraense. Mesmo assim, o percentual de transações imobiliárias de compra e venda não é negligenciável.

Dados da Tabela 10 mostram que o mercado imobiliário é bem mais dinâmico na Campina do que na Cidade Velha, visto que foram transacionados $16,7 \%$ dos imóveis existentes no primeiro contra apenas $8,2 \%$ no segundo. No segmento de imóveis para atividades econômicas, o percentual de imóveis negociados em relação ao estoque existente foi de $18,6 \%$ na Campina, contra apenas $5,8 \%$ na Cidade Velha, algo esperado, considerando-se que 0 centro comercial tradicional se situa, em sua quase totalidade, na Campina.
Apesar do predomínio do uso habitacional ser maior no bairro da Cidade Velha $70,8 \%$ do total de imóveis contra $55,2 \%$ na Campina -, o mercado de moradias foi mais dinâmico no bairro da Campina, onde foram transacionados 15,2\% dos domicílios existentes, enquanto na Cidade Velha esse percentual foi de 9,3\%. Confrontando-se esse resultado com os da Tabela 5, de incremento percentual maior do número de domicílios particulares permanentes entre 1991 e 2010 na Cidade Velha, é possível inferir que o mercado informal de moradias é bastante expressivo nesse bairro. Assim, o mercado imobiliário formal não reflete, de forma plena, a procura por moradia nesse bairro.

Esses números do $\mathrm{CHB}$ revelam, portanto, que mesmo num contexto de degradação do espaço construído, em curso há bastante tempo, existem subespaços e mercados com características bastante diferenciadas nos bairros da Campina e da Cidade Velha. 
As transações imobiliárias de compra e venda funcionaram como operadoras das transformações espaciais no CHR e no CHB, tendo sido essas mudanças mais acentuadas no centro recifense do que no belenense. Assim, também na dinâmica das transações imobiliárias se manifestam similaridades e especificidades inter e intracentros históricos. Similaridades que decorrem de processos mais gerais de produção do espaço urbano, que resultam tanto em dificuldades de adaptação das edificações dos centros históricos às demandas do mercado por imóveis residenciais e comerciais, quanto da impossibilidade de compatibilizar os interesses da conservação com as necessidades do capital imobiliário de reprodução ampliada. Das maneiras como cada centro e/ ou seus subespaços vêm sendo incorporados (ou não) às dinâmicas do capitalismo em suas diversas escalas parecem advir as especificidades encontradas.

\section{Conclusões}

0 trabalho revelou que os três centros históricos estudados mantêm certo dinamismo econômico e apresentam áreas mais degradadas e mais conservadas. Dos três, claramente, o de Belém é onde o patrimônio construído está em pior estado em termos de degradação.

Desde final do século XIX, os três centros têm sido objeto de ações destinadas à recuperação de prédios, de infraestruturas urbanas e de espaços públicos. A natureza das intervenções estatais, particularmente aquelas realizadas após os anos 1990, não apenas influenciou na conservação de partes dessas centralidades, como colaborou para as alterações nas funcionalidades dos seus subespaços com implicações nos seus respectivos mercados imobiliários.

No CHR, tais políticas públicas (incentivo fiscal, dotação e/ou renovação de infraestruturas, políticas nacionais setoriais, etc.) têm estado fortemente relacionadas ao processo de globalização da economia brasileira, o que tem proporcionado a recriação de porções do território desse centro histórico. Elas viabilizaram a implantação de empresas de TIC e de projetos turísticos de monta, no bairro do Recife, e de empresas relacionadas à educação superior, no de Santo Antônio, recriando as suas espacialidades. Em contrapartida, nos bairros de São José - inserido na globalização notadamente via circuito superior marginal - e da Boa Vista, a ausência do poder público tem contribuído para a reprodução das espacialidades preexistentes. Como consequência, a natureza e o dinamismo do mercado imobiliário foram distintos nesses dois conjuntos de bairros. Mostrou-se mais dinâmico no primeiro conjunto do que no segundo.

No $\mathrm{CHB}$, os investimentos realizados foram quase que exclusivamente públicos, e não foram acompanhados de uma política sistemática de mudança estrutural no perfil das atividades terciárias tradicionais. $\mathrm{A}$ instalação de museus, a recuperação física de imóveis e espaços públicos relevantes, assim como os incentivos concedidos à implantação de atividades culturais e turísticas não foram suficientes para mudar o caráter de espaço terciário cada vez mais popular. Nesse contexto, tem sido principalmente por meio do circuito superior marginal - em especial sob a influência de comerciantes asiáticos - que o CHB tem se inserido no processo de globalização. Esses 
migrantes instalam lojas populares e depósitos de produtos para abastecer ambulantes, ao tempo em que compram ou alugam imóveis para suas residências na proximidade da área comercial. Por transacionarem produtos de baixo preço, reforçam a tendência à popularização e à proliferação do uso comercial nos imóveis do $\mathrm{CHB}$, especialmente no bairro da Campina. Ressalte-se que essa forma de inserção onera e dificulta, sobremaneira, a recuperação/preservação do patrimônio arquitetônico e cultural. Os dados ainda mostraram que, não obstante a crescente quantidade de imóveis desocupados e degradados, a demanda por imóveis para usos habitacional e terciários no CHB ainda é forte, o que se explica quer pela centralidade por ele exercida na metrópole e junto às comunidades ribeirinhas - o que o mantém como o principal centro de trocas de mercadorias e de prestação de serviços regional -, quer pelas vantagens locacionais que oferece, amplificadas diante da grave crise de mobilidade urbana vivenciada na atualidade.

No CHSL, foi possível identificar uma situação paradoxal: a presença, ao mesmo tempo, de grandes investimentos do poder público visando à reabilitação da área e o crescimento do processo de abandono e da consequente degradação. Os investimentos incrementaram o turismo internacional e repercutiram no crescimento do setor educacional na área, tanto público como privado, principalmente com a instalação de cursos superiores. Tal situação tem resultado, como consequência, na perda de uma das características mais fortes dessa área que, até a década de 2010, era o centro comercial, de serviços e institucional mais importante da cidade.

A análise realizada mostrou que existem similitudes e singularidades nos processos de transformação e reprodução socioespacial dos centros históricos das cidades brasileiras, todos operados pelo mercado imobiliário. Também ficou evidente que, nesses centros, esse mercado ora contribui para a manutenção ou reprodução ampliada das áreas degradadas, ora para a recriação de outras, o que lhes confere, nesse último caso, novas funções técnico-econômicas. Assim, espaços dos centros históricos são inseridos no processo de globalização da economia, tanto pela via do circuito superior da economia (áreas em processo de requalificação), quanto pela via do seu circuito inferior, na qual persistem áreas degradadas. 
[I] https://orcid.org/0000-0003-3596-1736

Universidade Federal de Pernambuco, Centro de Artes e Comunicação, Departamento de Arquitetura e Urbanismo, Programa de Pós-Graduação em Desenvolvimento Urbano. Recife, PE/Brasil. norma_lac@yahoo.com.br

[II] https://orcid.org/0000-0001-7588-1680

Universidade da Amazônia,Curso de Arquitetura e Urbanismo, Programa de Pós-Graduação em Desenvolvimento e Meio Ambiente Urbano. Belém, PA/Brasil.

helenazt@uol.com.br

[III] https://orcid.org/0000-0002-3366-4992

Universidade da Amazônia, Programa de Pós-graduação em Desenvolvimento e Meio Ambiente Urbano. Belém, PA/Brasil.

lobo2502@gmail.com

[IV] https://orcid.org/0000-0002-3778-4465

Universidade Estadual do Maranhão. Curso de Arquitetura e Urbanismo. São Luís, MA/Brasil. marlucewall@gmail.com

\section{Notas}

(*) Este artigo decorre da pesquisa Mercado imobiliário em centros históricos das cidades brasileiras. Contou com o apoio do Conselho Nacional de Desenvolvimento Científico e Tecnológico (CNPq), Fundação de Amparo à Ciência e Tecnologia do Estado de Pernambuco (Facepe), Universidade Federal de Pernambuco (UFPE), Fundação para o Desenvolvimento da Amazônia (Fidesa), Fundação de Apoio à Pesquisa e ao Desenvolvimento Científico e Tecnológico do Maranhão (Fapema) e Universidade Estadual do Maranhão (Uema).

(1) Este item resume parte do texto elaborado por Lacerda e Anjos (2015).

(2) Dese, conceito desenvolvido por Lipietz, em 1974, e explicado mais adiante.

(3) No mesmo movimento, a porção do centro deixada de fora pelo tombamento federal foi tombada pelo estado do Maranhão em 1986 (Andrés, 1998, p. 106). Cumpriam-se, pelo menos em parte, as recomendações de Viana de Lima (1972) e de Michel Parent (1967), que defendiam o tombamento extensivo.

(4) Lipietz (1974) substitui o termo preço do solo, que faz referência ao econômico, por tributo fundiário, para insistir nos fundamentos não econômicos da determinação dos preços do solo urbano. Dito de outra forma: ele renuncia a uma análise fundiária baseada no objeto (sua localização, sua proximidade dos equipamentos e serviços urbanos), para propor uma análise das estratégias dos agentes econômicos, reagrupados em classes sociais, cujas escolhas se manifestam na organização do espaço urbano. 
(5) Convém anotar que 2008 corresponde ao início do período de forte expansão dos preços imobiliários, decorrente da redução da taxa de juros dos financiamentos habitacionais e da flexibilização das regras de concessão desses financiamentos, começando a retrair-se em 2013, com a crise da economia brasileira (Lacerda e Anjos, 2015).

\section{Referências}

ALVES, J. E. D. e CAVENAGHI, S. (2012). Tendências demográficas, dos domicílios e das famílias no Brasil. Disponível em: <http://www.ie.ufrj.br/aparte/pdfs/tendencias_demograficas_e_de_ familia_24ago12.pdf>. Acesso em: 15 set 2016.

ANDRÉS, L. P. (1998). Centro Histórico de São Luís-Maranhão: Patrimônio Mundial. São Paulo, Audichromo.

BERNARDINO, I. L. e LACERDA, N. (2015). Centros históricos brasileiros: tensões entre a obsolescência imobiliária e a construção de novas espacialidades. Revista Brasileira de Estudos Urbanos e Regionais, v. 17, n. 1, pp. 61-74.

CORRÊA, A. J. L. (1989). O espaço das ilusões: planos compreensivos do planejamento urbano da Região Metropolitana de Belém. Dissertação de Mestrado. Belém, Universidade Federal do Pará.

LACERDA, N. e FERNANDES, A. C. (2015). Parque tecnológico: entre a inovação e a renda imobiliária no contexto da metrópole recifense (Brasil). Cadernos Metrópole. São Paulo, v. 17, n. 34, pp. 329-354.

LACERDA, N. e ANJOS, K. (2015). “A regulação da dinâmica espacial nos centros históricos brasileiros em tempos de globalização: o caso do Recife (Brasil)". In: FERNANDES, A. C.; LACERDA, N. e PONTUAL, V. (orgs.). Desenvolvimento, planejamento e governança: o debate contemporâneo em 30 anos de Anpur. Anpur.

LIMA, A. V. de (1972). Rapport et propositions pour la conservation, récupération et expansion de São Luís/Maranhão. São Luís, mimeo.

LIMA, D. B. O. (2015). A percepção dos agentes do mercado imobiliário sobre a preservação e a legis/ação do Centro Histórico de Belém. Dissertação de Mestrado. Belém, Universidade da Amazônia.

LIPIETZ, A. (1974). Le tribut foncier. Paris, François Mapero.

LOBO, M. A. A.; TOURINHO, H. L. Z. e MORHY, S. (2016). Reasons to live in historic centers: the case of Belem (Brazil). Revista do Departamento de Geografia Universidade de São Paulo. São Paulo, v. 32, pp. 97-107.

LUBAMBO, K. W. (1991). O bairro do Recife: entre o Corpo Santo e o Marco Zero. Recife, Cepe/ Fundação de Cultura da Cidade do Recife.

MERCÊS, S. S. S. das; TOURINHO, H. L. Z. e LÔBO, M. A. A. (2014). Locação social no Centro Histórico de Belém: investigação introdutória. Caderno CRH. Salvador, v. 27, n. 71, pp. 299-311. 
MINISTÉRIO DAS CIDADES. AGÊNCIA ESPANHOLA DE COOPERAÇÃO INTERNACIONAL PARA O DESENVOLVIMENTO (2008). Manual de reabilitação de áreas urbanas centrais. Brasília, Ministério das Cidades.

OLIVEIRA, J. M. G. C. de (1992). Produção e apropriação do espaço urbano: a verticalização de Belém. Tese de Doutorado. São Paulo, Universidade de São Paulo.

PARENT, M. (1967). Protection et Mise en Valeur du Patrimoine Culturel Brésilien dans le Cadre du Développement Touristique et Économique. São Luís. Mimeo.

PENTEADO, A. R. (1968). Belém: estudo de geografia urbana. Coleção Amazônica, Série José Veríssimo. Belém, Universidade Federal do Pará.

REYNALDO, A. (1998). Las catedrales sieguem sendo blancas: un studio sobre la política de tratamiento del centro antiguo de Recife (Brasil). Tese de Doutorado. Barcelona, Universitat Politècnica de Catalunya.

SANTOS, M. (2008). O espaço dividido: os dois circuitos da economia urbana. São Paulo, Editora da Universidade de São Paulo.

SILVEIRA, M. L. (2007). Metrópolis brasileñas: un análisis de los circuitos de la economía urbana. Revista Eure. Santiago de Chile, v. 33, n. 100, pp. 149-164, dic. Disponível em: <http://www.scielo.cl/ scielo.php?script=sci_arttext\&pid=S0250-71612007000300009>. Acesso em: 4 out 2017.

SOUZA, A. O. de (1999). Patrimônio São Luís. Estudo sobre a sustentabilidade do processo de conservação do patrimônio cultural edificado. Dissertação de Mestrado. Recife, Universidade Federal de Pernambuco.

VENANCIO, M. W. C. (2009). “Construção da cidade dispersa e invenção da cidade histórica: as centralidades contemporâneas em São Luís do Maranhão". In: PINHEIRO MACHADO, D. (org.). Tipo e Urbanismo: Novas Espacialidades no Século XX. Porto Alegre, Marcavisual.

(2011). Urbanização dispersa em São Luís: tensões entre expansão e centro. Tese de Doutorado. Rio de Janeral, Universidade Federal do Rio de Janeiro.

Texto recebido em 19/fev/2018

Texto aprovado em 12/abr/2018 
